\title{
Yavuz Sabuncu İçin
}

\author{
Prof. Dr. Fazıl Sağlam \\ Yıldız Teknik Üniversitesi \\ İktisadi ve İari Bilimler Fakültesi
}

Bu konuşmada önce Yavuz'a karş̧ içimde gizli kalan bir vicdan azabını dile getirmem gerekiyor. Ben üniversiteden ayrıldığımda kürsümün iki hocası, Bahri Savcı ve Cem Eroğul görevden alınmıştı. Aynı gün Mülkiye Dekanı'nın, dekan yardımcılarının ve bu arada Tuncer Bulutay gibi bașka Mülkiye hocalarının da görevlerine son verilmişti. Bu haksızliğa dayanamayıp istifa ettikten sonra, Anayasa Hukuku kürsüsünün ağırlığı Yavuz Sabuncu'nun üzerine yıkıldl. Muammer Aksoy Hoca zaten çok daha önce siyasete atılmak üzere Mülkiye'den ayrlmıştı. Bir süre sonra Mümtaz Hoca da siyasete geçince Yavuz'un üstündeki ăğrlık dayanılmaz boyutlara ulaştı. Ama ben Yavuz'un bundan yakındığını hiç duymadım. Bu ağır yükü hiç yüksünmeden ve sitem etmeden taşıld. Şimdi biliyorum ki o benden çok daha dirençli ve güçlüydü.

Yavuz, hepimize şaşırtacak boyutta geniş bir bilgi birikimine sahipti. Adeta canlı bir ansiklopedi gibiydi. Bu bilgi hazinesinden titizlikle süzülmüs, her satırı özenle seçilmiş ürünler verdi. Ama asıl bu ürünlerin giderek zenginleşeceği ve anayasa ve siyasal yaşama büyük katkılar sağlayacă̆ı bir zamanda onu kaybettik. Acımızı dayanılmaz kılan budur.

Yavuz'un beni en çok etkileyen özelliği, sahip olduğu keskin gözlem yeteneği ve yer yer iğneleyici bir ironiye kayan eleştirel bakış açısı olmuştur. İnsanı uyaran ve alışılmışı sorgulayan ve her zaman özgürlük ve demokrasi yönünde işleyen bir özelliktir bu. Onun bu özelliğine başvurma ihtiyacını hep hissetmişimdir ve her zaman da gerekli uyarlları almışımdır. İște Yavuz'un bıraktı̆̆ değildir.

Arayacă̆ımız bir başka özelliği daha var ki ona rastlamak artık giderek güçleşiyor: Dürüst ve güvenilir bir dost; tarihin güzelliklerinden süzülen ince bir zevkle bezenmiş bir yaşam biçimi ve böyle bir yaşama olan özen ve tutku. 
10 • Ankara Üniversitesi SBF Dergisi • 62-3

Sevgili Yavuz, seninle aynı kürsüde çalışmak ve içten bir dostluğu paylaşmak büyük bir zenginlikti; seni hiç unutmayacağız ve hep arayacă̆ız. Işılk içinde yat. 